\title{
THERAPEUTICAL APPROACH WITH DENTAL IMPLANTS IN HYPODONTIA
}

\author{
Marija Peeva Petreska ${ }^{1}$ Daniela Veleska Stevkovska , Biljana Dzipunova², Meri Pavlevska ${ }^{3}$, Sonja Apostolska \\ ${ }^{1}$ Department of Oral Surgery, Faculty of Dentistry in Skopje, University "Ss. Cyril and Methodius", FYR Macedonia \\ ${ }^{2}$ Department of Orthodontics, Faculty of Dentistry in Skopje, University "Ss. Cyril and Methodius", FYR Macedonia \\ ${ }^{3}$ Department of Pediatric and Preventive Dentistry, Faculty of Dentistry in Skopje, University "Ss. Cyril and Methodius", \\ FYR Macedonia \\ ${ }^{4}$ Department of Restorative Dentistry and Endodontics, Faculty of Dentistry in Skopje, University "Ss. Cyril and \\ Methodius", FYR Macedonia
}

\section{TERAPIJSKI PRISTUP ZUBNIM IMPLANTATIMA U HIPODONCIJI}

\author{
Marija Peeva Petreska1, Daniela Veleska Stvekovska1, Biljana Džipunova², Meri Pavlevska ${ }^{3}$, Sonja Apostolska ${ }^{4}$ \\ ${ }^{1}$ Katedra za oralnu hirurgiju, Stomatološki fakultet u Skoplju, Univerzitet „,Sveti Ćirilo i Metodije“, BJR Makedonija \\ ${ }^{2}$ Katerdra za ortodonciju, Stomatološki fakultet u Skoplju, Univerzitet ,Sveti Ćirilo i Metodije“, BJR Makedonija \\ ${ }^{3}$ Katedra za dečju i preventivnu stomatologiju, Stomatoloski fakultet u Skoplju, Univerzitet „,Sveti Ćirilo i Metodije“, BJR \\ Makedonija \\ ${ }^{4}$ Katedra za bolesti zuba i endodonciju, Stomatoloski fakultet u Skoplju, Univerzitet „,Sveti Ćirilo i Metodije“, BJR Makedonija
}

\section{ABSTRACT}

Hypodontia in the permanent dentition is a significant clinical challenge, particularly in the treatment of adolescent patients who are missing anterior teeth. They have severe aesthetic and psychological disorders and satisfying the aesthetic moment is the main motivation for treatment. But, the goal in the management of hypodontia for the therapist is not only to improve the aesthetics but also to accomplish a good masticatory function with long lasting and predictable results. The selection of an appropriate therapeutic option needs multidisciplinary approach and team coordination, first during treatment planning and then for determining the most appropriate time and method for subsequent orthodontic, surgical and prosthetic treatment. The aim of the authors is, through the presentation of clinical material with hypodontia of the lateral incisors in maxilla and mandible, to show the need of multidisciplinary approach in the treatment of hypodontia using dental implants in the aesthetic region, and to emphasize the critical moments of the surgical aspects in order to achieve the best aesthetic and functional outcome. Good cooperation with the patients and their family is of particular importance, especially because of the long interval of orthodontic and surgical treatment until the final results are achieved.

Key words: tooth diseases; dental implants; surgical procedures, operative.

\section{INTRODUCTION}

Hypodontia, with prevalence in the permanent dentition in the range from $2.3 \%$ to $11.3 \%$, depending on the population investigated, or $4.6-6.3 \%$ within the dentition of white European populations, is the most common developmental anomaly in humans. Hypodontia is the most frequently used term, but many other terms appear in the literature to describe a reduction in the

\section{SAZ̈ETAK}

Hipodoncija u stalnoj denticiji predstavlja izuzetan klinički izazov, posebno kada je u pitanju lečenje adolescentnih pacijenata, kod kojih postoji nedostatak frontalnih zuba. Oni imaju ozbiljne estetske i psihološke poremećaje $i$ zadovoljenje estetskog aspekta je glavna motivacija lečenja kod adolescenata, ali i cilj u odlučivanju terapeuta za poboljšanje estetike kod hipodoncije i prirodno obnavljanje mastikatornih funkcija sa dugoročnim $i$ predvidljivim rezultatima. Izbor terapije zahteva timski rad koordiniranog modela, pravilni plan terapije, zatim određivanje najpogodnijeg vremena $i$ načina izvođenja terapije i konačno sprovođenje ortodontske, oralnohirurske $i$ restorativne terapije. Kroz prezentaciju kliničkog materijala, $u$ slučaju hipodoncija lateralnih inciziva u maksili $i$ mandibuli, prikazan je multidisciplinarni pristup u terapiji sa dentalnim implantatima $i$ postizanje maksimalnih rezultata sa estetske i funkcionalne tačke gledista. Ovo je kompleksno lečenje, zbog dugog perioda sa ortodontskog i hirurškog aspekta, traži $i$ dobru komunikaciju sa pacijentima $i$ njegovim roditeljima ili članovima njegove uže porodice.

Ključne reči: bolesti zuba; dentalni implantati; hirurške procedure, operativne.

number of teeth: aplasia, congenitally missing teeth, absence of teeth, agenesis of teeth, lack of teeth, oligodontia or anodontia $(1,2)$.

Clinical examination together with panoramic X-ray in detecting or confirming dental development is crucial. Because all permanent tooth crowns mineralize by the age of six, except for the third molars, diagnosis of tooth agenesis in the permanent dentition should be made after this age. The importance of an accurate diagnosis and an effective treatment plan with appropriate coordination of timing of interventions should involve a multidisciplinary 
team approach with the participation of pedodontist, orthodontist, oral and maxillofacial surgeon and prosthodontist. However, hypodontia presents challenges for the clinician with variety of treatment options, depending upon the severity of the case.

In the treatment concept, there are many alternatives: prosthodontics therapy in simple cases, orthodontic space closure (spontaneous or with conventional orthodontic modalities), orthodontic space redistribution or space opening for prosthetic replacements or rehabilitation with dental implants or autotransplantation (3).

\section{THE PATIENTS}

This paper will present two of our clinical cases, to illustrate a therapeutic approach with dental implants to replace congenitally missing lateral incisors in the upper and in the lower jaw.

\section{The first case}

Male, aged 19 years and 6 months, reported for dental treatment to the University Dental Clinical Center "St. Pantelejmon" in Skopje. His general medical history was not significant, with family history of hypodontia in one parent. Oral hygiene and gingival status were good and no caries was found. Radiographic examination confirmed clinical absence and developmentally missing of both lateral incisors in the lower jaw-hypodontia of 32 and 42, with persistent deciduous tooth on the right side (figure 1), and space closed in the left side.

Preoperative models were mounted and analyzed. Our therapeutical plan was orthodontic treatment in the beginning, for redistribution of the space and correction of deep byte and as final, rehabilitation with dental implants. The patient refused the orthodontic treatment with request for dental implant on the right side, as soon as possible to

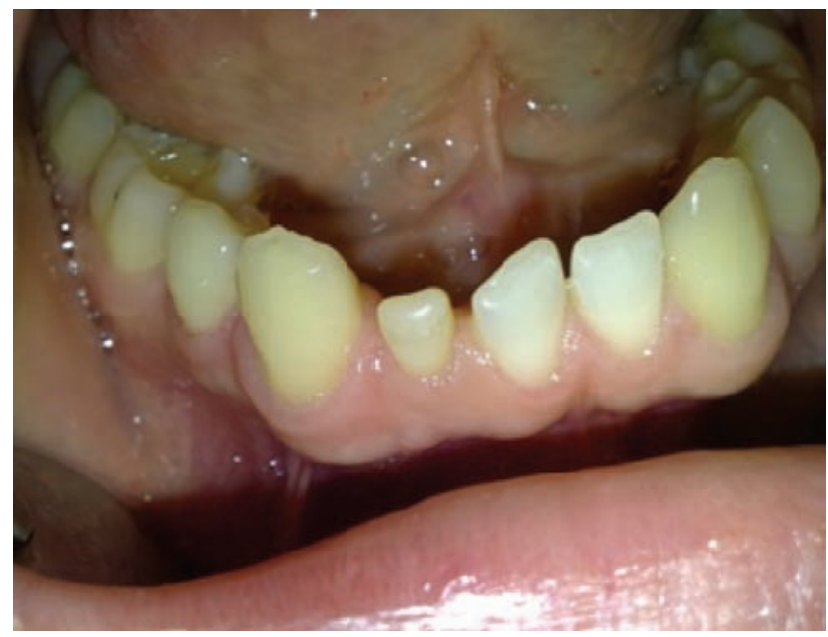

improve the aesthetic moment. After correction of the byte with restorations on the occlusal side of the molars, the immediate implant placement with extraction of deciduous tooth was performed.

Intraoperative view was as following: traumatic occlusion made resorption of the vestibular lamina on the central permanent incisor and the lateral deciduous tooth, this indicated augmentation procedure together with immediate placement of implant (figure 2). After the preparation of the implant bed, we inserted Ankylos ${ }^{\circledR} \mathrm{CX}$ implant, $14 \mathrm{~mm}$ long with $3.5 \mathrm{~mm}$ diameter, from Dentsply Friadent, with application of the xenogenic bone substitute materials - BiO-Oss ${ }^{\circledR}$ spongiosa granules, Geistlich Biomaterials (figure 3). Provisional crown was made immediately after the implantation without occlusal contact (figure 4). A postoperative radiograph was taken to verify proper implant placement and to assess the relationship of the implant to surrounding structures. The patient was instructed to rinse with chlorhexidine for 60 seconds twice a day for 2 weeks.

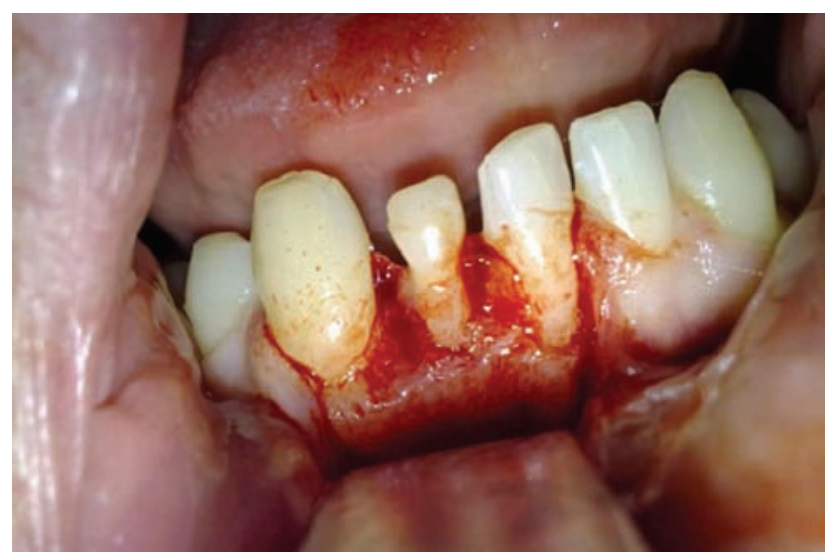

Figure 2. Sufficient mesiodistal space. Resorption of the bone on the central permanent incisor and the lateral deciduous tooth and resorption of the root of the lateral deciduous tooth.

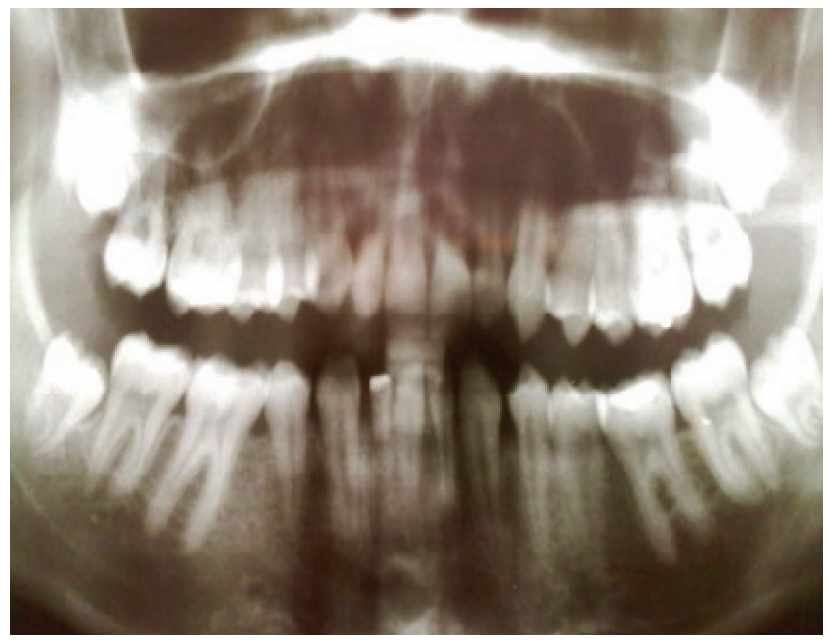

Figure 1. Clinical view and X-ray examination. 


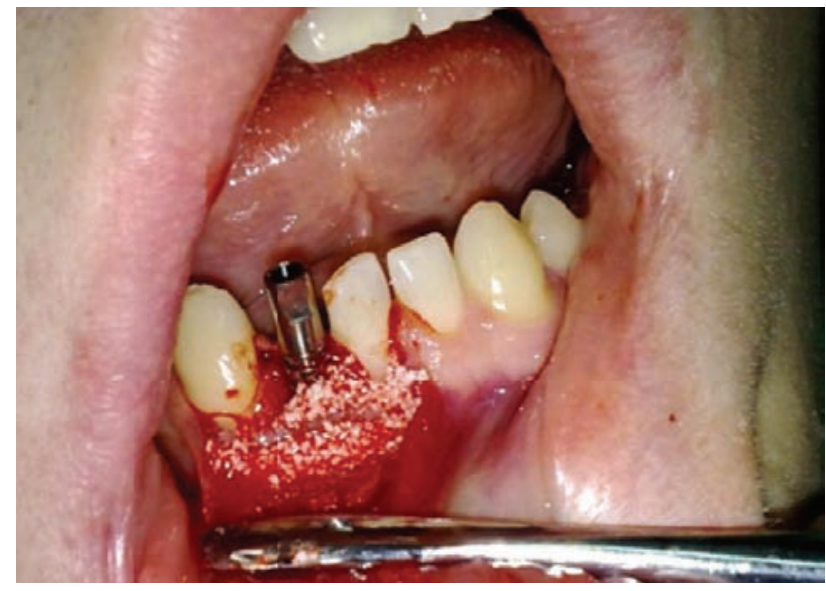

Figure 3. Implant insertion and application of the bone graft material Bio-Oss ${ }$.

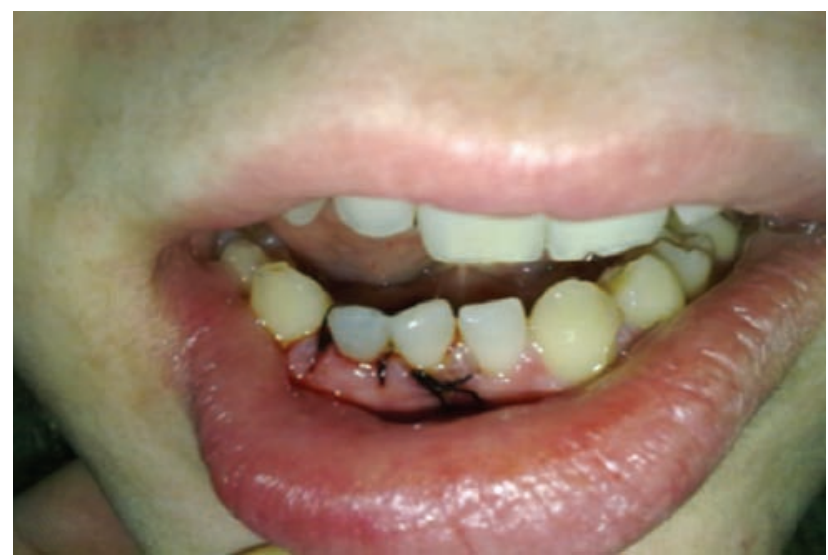

Figure 4. Provisional crown was made immediately after implantation without occlusal contact.

An antibiotic regimen of amoxicillin $1000 \mathrm{mg}$, was prescribed to be taken an hour before implant surgery and for the next 5 days. After 4 months an abutment was placed and after a few years a control radiograph was taken (figures 5, 6).

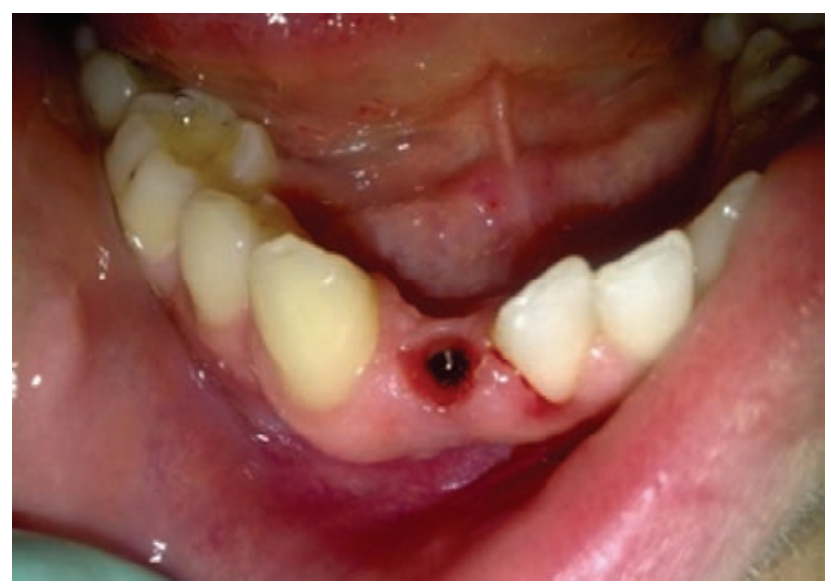

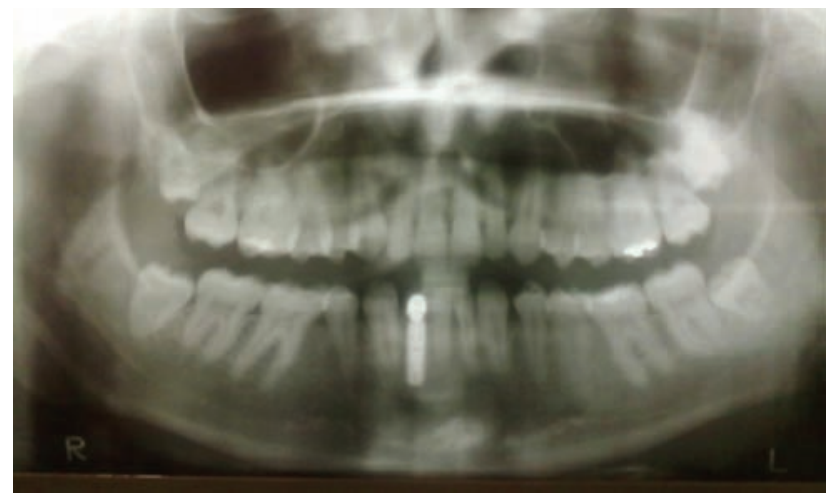

Figure 6. X-ray after 3 years.

\section{The second case}

A 20-year-old female patient with no medical contradictions presented for replacement of the maxillary lateral incisors (figure 7). An outside orthodontic specialist completed treatment 6 months before and the adjacent teeth were in ideal position. Patient wore a removable retainer which also restored UR2 UL2. There was $7.0 \mathrm{~mm}$ between the central incisor and cuspid. The problem in this patient was the hard and soft-tissue loss,

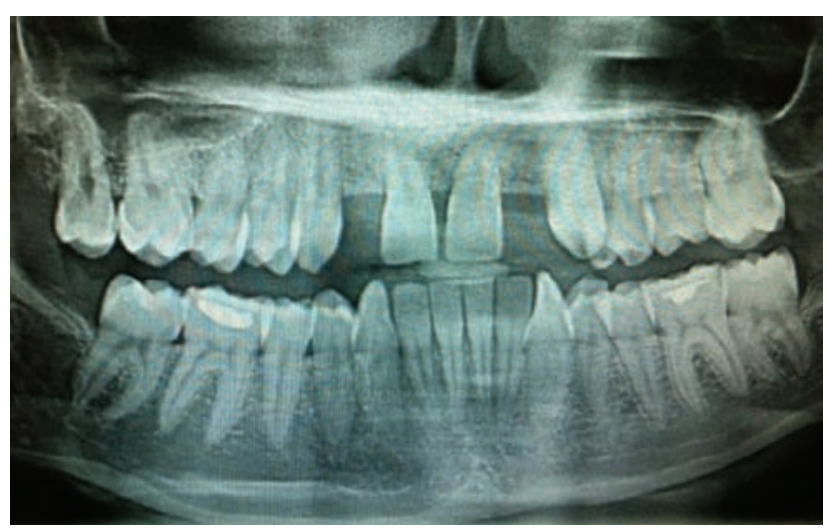

Figure 7. Hypodontia of the UR2 UL2.

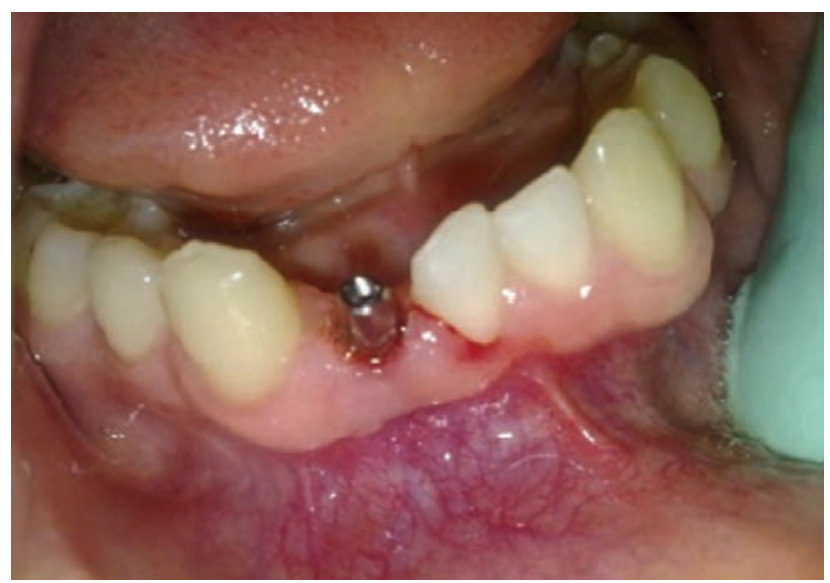

Figure 5. Intraoral view after 4 months without and with abutment. 

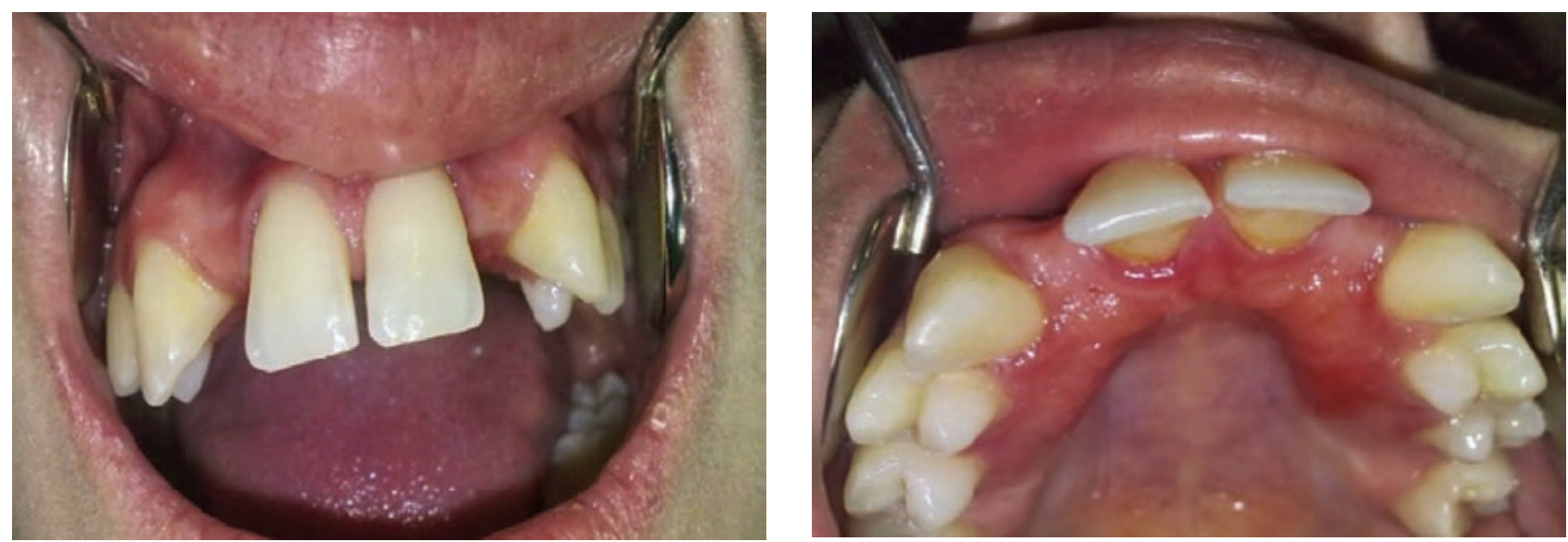

Figure 8. Hard and soft-tissue loss, especially reduction of the buccal alveolar bone.

especially reduction of the vestibular alveolar bone, obvious in clinical examination and on X-ray (figure 8).

The advanced resorption of the alveolar bone is a problem for implant placement with limitations of drilling into an atrophic ridge. There are several methods to enhance the bone volume depends of the severity of resorption, like bone condensing and bone spreading

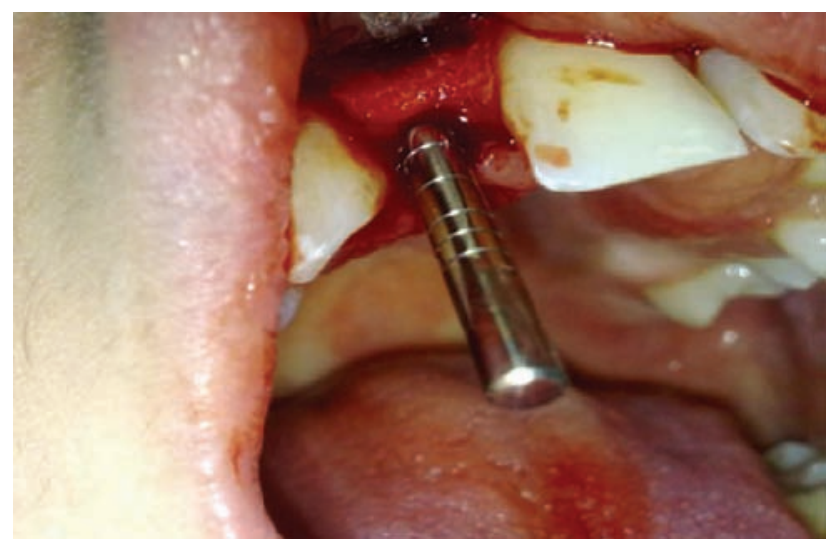

Figure 9. Bone spreading technique (BST) for enhance the bone volume and testing the position and angulation of the implant bed.

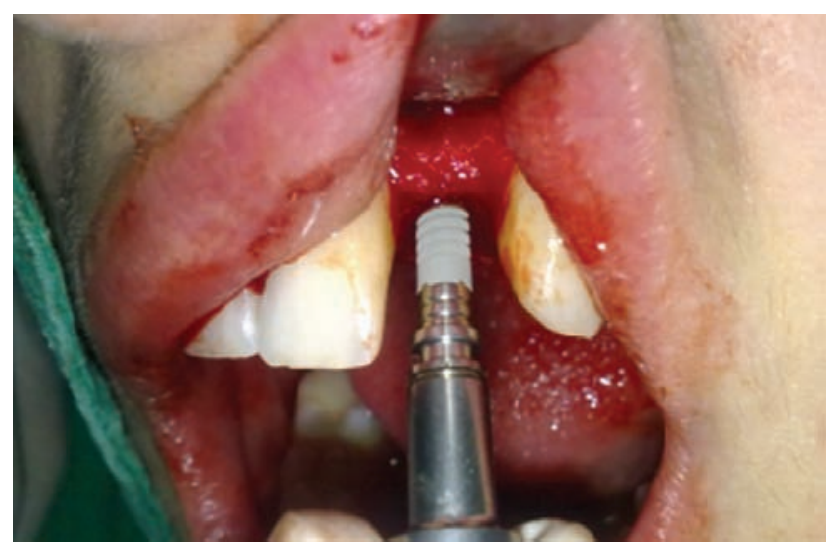

technique which are recommended in a soft bone as well as it is in maxilla. Both techniques were performed to enhance and condense the bone in maxilla and we did not use bone graft material (figure 9).

Ankylos CX Implants A11 (Dentsply®, Friadent), were selected to replace the lateral incisors. The implants were inserted $0.5 \mathrm{~mm}$ in subcrestal position for maximum aesthetic results (figure 10). The X-ray after 4 months (figure 11), showed ideal implant positions without any

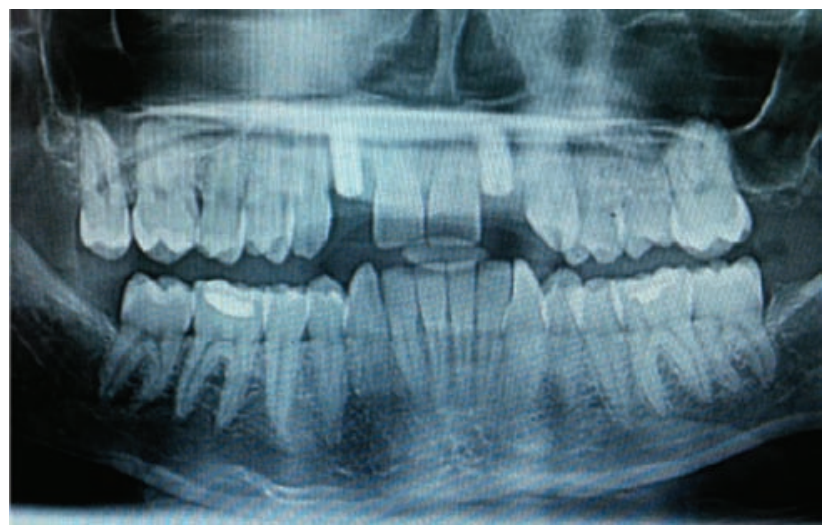

Figure 11. X-ray after 4 months.

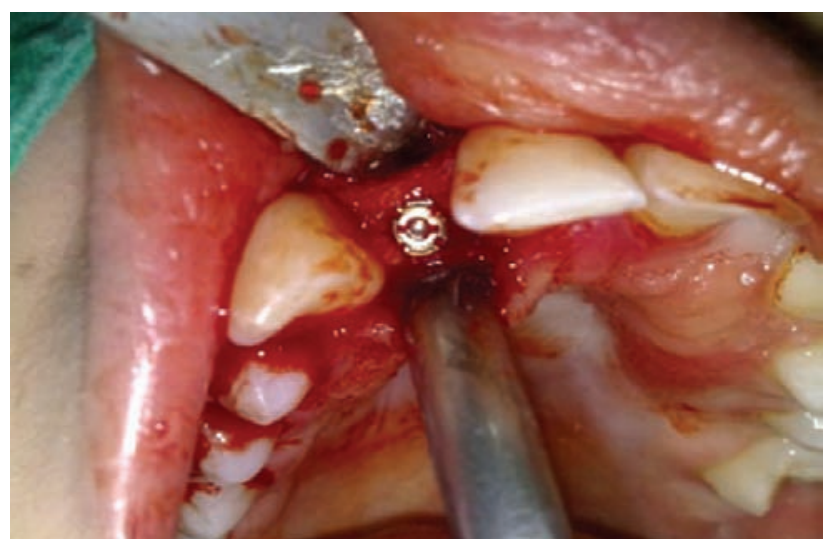

Figure 10. Implant placement and final subcortical position of the implant for maximum esthetic results. 
bone resorption around them and we performed the final prosthetic restoration using zirconia abutments and crowns (figure 12).

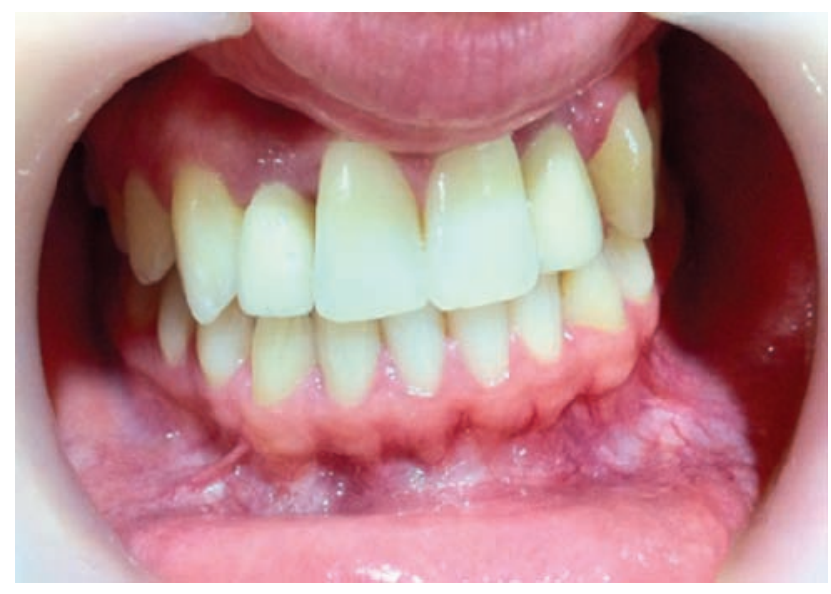

Figure 12. Final prosthetic restoration.

\section{DISCUSSION}

In some cases conventional crown and bridge treatment offers many advantages as a therapeutic choice for tooth replacement - the treatment time is considerably shorter when compared to implant-based treatment. This approach can also be comparatively cost-effective with excellent aesthetic results. The disadvantage is the preparation of unaffected teeth which invites a multitude of future periodontal and endodontic problems. Orthodontic space closure or space redistribution is usually a necessary treatment modality for missing maxillary lateral incisors. The most obvious advantage of this approach is the elimination of the need for a lifelong maintenance of a fixed restoration as well as the consequences of preparing unrestored teeth. Other advantages include the permanent nature of a completed treatment and the avoidance of interim provisional partial dentures. However, with the completion of this treatment there is a tendency for the space between the anterior teeth to reopen. The major disadvantage of this treatment relates to the positioning of the maxillary cuspid tooth in the lateral incisor position, as well as the shape and color difference among maxillary cuspids, maxillary central incisors, and mandibular incisors.

Dental implants have revolutionized the restoration of edentulous and partially edentulous patients, including individuals who are congenitally missing maxillary or mandibular lateral incisors. The advantages of this treatment option include longevity, preservation of adjacent teeth, aesthetics, but implant therapy may take 46 months to place and prosthetic to restore the implant. Another disadvantage of implant therapy is a possibility of implant failure after periimplantitis, which often results in bone loss, bone grafting and retreatment with significant cost. Despite the shortcomings of implant therapy, it has emerged as a conservative and predictable method for replacing missing congenital lateral incisors.

In young persons, proper timing of implant placement is important. There is a danger in placing implants too early in development, because implants are not capable of compensatory eruption and behave like ankylosed teeth. There is general agreement that implant placement should be delayed until after puberty, when growth and skeletal development are complete. During the interim period, preservation of alveolar bone volume is important, which means that the hypodontia requires a coordinated plan of therapy and an appropriate amount of time for the specialist treatment.

The timing of the extraction of retained primary teeth is also critical for the final result. Usually it is better to delay the removal of retained primary teeth to maintain the surrounding dentoalveolar bone, if the plan is rehabilitation with dental implants. Of particular importance is the preliminary detailed planning and detailed analysis of the jaws and natural teeth which are present. It is important that there is sufficient space to place the implants with adequate bone quality and quantity to provide good anchorage. The quantity and morphology of the bone have to be assessed preoperatively in all dimensions using clinical and radiology examinations. Finnema and associates (4) reported implant survival rates of $86 \%$ and $96 \%$ for the mandible and maxilla, after the observation period of 3 years in 13 patients with a total of 87 implants. Creton and associates (5), reported of $89.8 \%$ survival rate in a 5-year period of evaluation on the 214 placed implants in patients with severe hypodontia, which is acceptable, regarding compromised anatomic situation and the complexity of treatment. Durstberger and associates (6) observed an implant survival rate of $96 \%$ after 5 years in 13 patients and 69 implants.

In recent years, several studies on immediate loading of implants have demonstrated that it is possible to achieve success comparable to the classic 2-stage approach. Hahn and associates (7) reported a survival rate of $95.7 \%$ of immediate loading of implants placed in the aesthetic zone. All studies recommended maximization of implant stability by using longer implants and eliminating occlusal contact in centric and excursive movements. Also, there are contraindications to implant treatment for replacement of congenitally missing lateral incisors, like malposition roots of the proximal teeth. This often requires orthodontic treatment before implant placement, or smaller-diameter of the dental implants.

In conclusion, there are several treatment modalities available to replace missing lateral incisors and each of them has advantages and disadvantages that should be considered with patients and parents especially because the treatment duration for patients with hypodontia may 
extend over many years. Dental implants are a predictable and successful treatment option for replacing missing congenital lateral incisors and although a number of therapeutic alternatives should be considered, treatment with implants allows the clinician to avoid the preparation of adjacent teeth and provides long-term solution to the clinical problem.

\section{CONFLICT OF INTEREST}

The authors declare no conflict of interest relating to the manufacturing, distribution, selling and promotion of dental devices and equipments mentioned in the article.

\section{REFERENCES}

1. Kaste SC, Goodman P, Leisenring W, et al. Impact of radiation and chemotherapy on risk of dental abnormalities: a report from the Childhood Cancer Survivor Study. Cancer 2009; 115: 5817-27.

2. Nunn JH, Carter NE, Gillgrass TJ, et al. The interdisciplinary management of hypodontia: background and role of paediatric dentistry. Br Dent J 2003; 194: 245-51.

3. Kristenson L, Lagerstrom L. Autotransplantation of teeth in cases with agenesis or traumatic loss of maxillary incisors. Eur J Orthod 1991; 13: 486-92.

4. Finnema KJ, Raghoebar GM, Meijer HJ, Vissink A. Oral rehabilitation with dental implants in oligodontia patients. Int J Prosthodont 2005; 18: 203-9.

5. Creton M, Cune M, Verhoeven W, Muradin M, Wismeijer D, Meijer G. Implant treatment in patients with severe hypodontia: a retrospective evaluation. J Oral Maxillofac Surg 2010; 68: 530-8.

6. Durstberger G, Celar A, Watzek G. Implant-surgical and prosthetic rehabilitation of patients with multiple dental aplasia: a clinical report. Int J Oral Maxillofac Implants 1999; 14: 417-23.

7. Hahn J. Single-stage, immediate loading, and flapless surgery. J Oral Implantol 2000; 26: 193-8. 